\title{
Use of Self-Adhesive Resin Cements in Dentistry: a Literature Review
}

\section{Uso de Cimentos Resinosos Autoadesivos em Odontologia: uma Revisão da Literatura}

\author{
João Marcos Carvalho Silva*a; Raíssa Alves Feitosa ${ }^{\text {; }}$ : Danyege Lima Araújo Ferreira ${ }^{\text {; }}$ Mila Oliveira Santos Viana ${ }^{a}$
}

\author{
${ }^{a}$ Centro Universitário UniFacid, Dentistry Course. PI, Brazil. \\ *E-mail: joao_marcoscs@live.com \\ Recebido em: 08/09/2020 \\ Aprovado em: 04/12/2020
}

\begin{abstract}
Self-adhesive resin cements (SARCs) are cementing agents and have the objective of simplifying adhesive cementation, with a simplified use protocol. The aim of this article was to review the literature on SARCs with a focus on the advantages of their use, highlighting their adhesion and biocompatibility mechanism. Thus, the Health Sciences Descriptors "Self-Adhesive Resin Cement", "Dental Cements", "Adhesion" and "Dental Prosthesis" were used, as well as their Portuguese counterparts in the online databases SciELO, PubMed and Bireme in the period of time between the years 2000 to 2020. According to the studies, SARCs have excellent physical and mechanical properties, which include low solubility in the oral environment, adhesion to the dental substrate and the prosthetic part, color mimicry, biocompatibility and fluoride release, in addition to being applied in a single step, optimizing the operator's working time. In addition, self-adhesive cements seem to offer a promising new approach in indirect restorative procedures, which may present a performance similar to conventional ones, however more studies are needed to support their long-term applicability.
\end{abstract}

Keywords: Resin Cements. Dental Cements. Adhesion. Dental Prosthesis.

\section{Resumo}

Os cimentos resinosos autoadesivos (CRAAs) são agentes de cimentação e possuem o objetivo de simplificar a cimentação adesiva, com um protocolo simplificado de utilização. Assim, o objetivo deste trabalho foi revisar na literatura acerca dos CRAAs com enfoque nas vantagens de sua adequada utilização, evidenciando seu mecanismo de adesão e biocompatibilidade. Dessa forma, foram utilizados os descritores em Ciências da Saúde (DeCS) "Cimento Resinoso Autoadesivo", "Cimentos Dentários", "Adesão" e "Prótese Dentária", assim como seus correspondentes na língua inglesa nas bases de dados online SciELO, PubMed e Bireme no período de tempo entre os anos 2000 a 2020. De acordo com os estudos, os CRAAs apresentam excelentes propriedades físicas e mecânicas, que incluem baixa solubilidade no meio bucal, adesão ao substrato dental e a peça protética, mimetização de cores, biocompatibilidade e liberação de fluoretos, além de serem aplicados em uma única etapa clínica, otimizando o tempo de trabalho do operador. Além disso, os cimentos autoadesivos oferecem uma nova abordagem promissora em procedimentos restauradores indiretos, podendo apresentar um desempenho semelhante aos convencionais, porém são necessários mais estudos que sustentem sua aplicabilidade a longo prazo.

Palavras-chave: Cimentos de Resina. Cimentos Dentários. Adesão. Prótese Dentária.

\section{Introduction}

Currently, there is a growing demand for aesthetic dental procedures that restore the lost function and smile harmony. This demand constantly causes the development of new materials that can meet the functional and aesthetic requirements necessary for the longevity of restorative treatment and the optimization of the dental surgeon's working time ${ }^{1}$.

Among the demand for aesthetic procedures sought by the patients, there is an indication of indirect restorative treatments, such as the installation of fixed prostheses or implants. Therefore, in order for these to have excellent clinical performance, all working steps must be performed accurately, including the choice of an ideal cement agent ${ }^{2}$.

In view of this, an ideal cement agent can be defined as the one presenting biocompatibility, adhesion to the dental substrate and the prosthetic piece, resistance to chewing efforts, low solubility and that promotes sealing in the toothrestoration interface, preventing any micro-infiltrations that, by chance, may cause failure of the restorative treatment ${ }^{3}$.

Four large groups of cement agents are used for prosthetic cementation, such as zinc phosphate cement (CFZ), polycarboxylate cement (CP), glass ionomer cement (CIV) and resin cements (CRs). In view of the above, resin-based cements revolutionized the indirect restorative treatment because they present good adhesion properties between the internal prosthesis surface and the external surface of the prepared tooth, in addition to wear resistance. Since CFZ and $\mathrm{CP}$, despite having adequate mechanical resistance, are soluble in the oral environment ${ }^{4}$.

In addition, CRS are low viscosity composites that are 
excellently used as cement agents in indirect restorations, since they promote adequate sealing between dental substrate and restoration. These cements can be divided into three subgroups taking into account the pre-treatment of dental substrate before cementation: 1 - Conventional Resin Cement, where acid conditioning is performed separately, followed by the application of an adhesive system and finally, resin cement application; 2 - Self-conditioning Resin cement, a selfconditioning adhesive is applied to the dental substrate and then the cement; 3 - Self-Adhesive Resin cements (CRAAs) are used without the need to apply any adhesive systems ${ }^{2,5}$.

Thus, among the existing CRs, CRAAs demonstrate clinical advantages, such as decreased postoperative sensitivity and lower humidity susceptibility when compared to other cementing agents, in addition, they denote fluorides release capacity equivalent to CIV. Therefore, due to the fact that it has high professional acceptance, ease of application and, consequently, optimization of the operator's working time, being able to present a clinical performance similar to conventional CRs, CRAAs have been the cement agent of choice in fixed prosthesis. Thus, it is essential that the professional know its chemical composition, so that they understand the action mechanism of the material and have a critical view about its indications and contraindications, so that there is the long-term success of restorative treatment ${ }^{2,6}$.

Thus, the objective of the present study was to review in the literature about the CRAAs with a focus on the advantages of their adequate use, evidencing their adhesive mechanism and biocompatibility.

\section{Development}

\subsection{Methodology}

A review of the literature was carried out, using the descriptors in Health Sciences (DeCS) "Cimento Resinoso Autoadesivo", "Cimentos Dentários", "Adesão" and "Prótese Dentária”, as well as their correspondents in English, in the online Scientific Electronic Library Online (SciELO) databases, PubMed and Latin American and Caribbean Center on Health Sciences Information. (Bireme). Scientific literature review articles, clinical trials and laboratory research were included, available free of charge in full text between 2000 and 2020, in English and Portuguese languages. However, some studies of an excellent impact factor on the subject, dated prior to the established time frame, were included. Finally, studies that were not fully available and those that after reading, the titles and/or objectives did not have a direct link with the objective of this study were excluded.

\subsection{The importance of adequate cementation in indirect restorations}

Dental cements are widely used in rehabilitating and aesthetic dentistry, since they are necessary components to promote bonding and to give stability to the tooth-restoration complex. Therefore, so that the same can be used in the cementation of restorations, they must have low viscosity to develop the necessary runoff and fill the entire prepared tooth interface and internal prosthesis surface. In addition, they should confer retention or adherence, resistance and the gap sealing between the dental remnant and the prosthesis, giving longevity to prosthetic work ${ }^{5,7-9}$.

However, there are several types of dental cements available in the market today and that cover several cementing techniques. Therefore, the choice of an ideal cementation system should be based on factors related to the physical, mechanical and biological properties of the material, the type of dental preparation made by the professional, of the restorative material indicated for the case, in addition to the operator's preference and ease of material handling and that promotes durability in restorative treatment ${ }^{8,10}$.

Furthermore, the prosthetic parts, either partial or total, made from ceramics or metal alloys, must remain fixed and stable on the prepared tooth so that the prosthetic work can be considered adequate. Thus, the cement agent should be chosen from the clinical needs and possibilities of indication, since after cementation and adaptation of the restoration, there should be no recurrence of caries that cause the restorative treatment failure ${ }^{8,11-13}$.

\subsection{Applicability of Resin Cements (CRs)}

The acid conditioning technique of dental surface proposed by Buonocore in 1955, years later improved by Fusayama in 1979, allowed an understanding of the need for acid conditioning for better adhesion of resin restorative materials ${ }^{14-17}$. In addition, in parallel with these studies, in 1962, the first composite composed of Bis-GMA monomers, by Bowen, was developed, being a precursor to the development of new resin cement agents with the objective of being used in the cementation of resin, zirconia and metalbased restorations, in addition to intraradicular retainers ${ }^{18}$.

CRs are composed of Bis-GMA monomers and/or other low viscosity methacrylate and inorganic loads (lithium, aluminum and silicon oxide), united with each other by silane. However, depending on the product, inorganic loads may vary in variable diameters and weight ranging from $36 \%$ to $77 \%$ of the total weight of the resin matrix ${ }^{19}$.

CRs have better properties when compared to conventional dental cements (CFZ, CP and CIV) because, when associated with adhesive systems, they present an increase in fracture resistance and minimization of micro infiltrations 8 . Furthermore, CRs have other characteristics that lead them to be chosen by operators, including efficient adhesion in enamel and dentin, high compression resistance, low solubility in the oral environment, color mimicry capacity of dental substrates and ceramic restorative material, and ideal viscosity for the wetness of the entire tooth-restoration interface ${ }^{20,21}$.

The CRs group is divided into three subgroups: 
conventional resin cements, self-conditioning resin cements and self-adhesive resin cements, which differ about the need for acid preconditioning prior to the cement application, already mentioned previously ${ }^{2,5,9,10,23}$.

However, CRs have limitations on their use. Among them, the high sensitivity to humidity is highlighted, therefore, in the face of clinical situations where it is not possible to control this limiting factor, its use is not indicated, since moisture interferes with the adhesive process, causing restorative failure $^{8,21,22}$

\subsection{Self-Adhesive Resin Cements (CRAAs)}

CRAAs were developed and introduced into the market with the premise of overcoming the properties and limitations of the other conventional dental cements and also of the other subgroups of CRs, since the best properties of the other dental cements were combined in this group. This cement has an indication to be used on different substrates such as enamel, dentin, metals, ceramics and intraradicular retainers. Moreover, CRAAs release fluoride at the time of partial dissolution of glass particles similar to $\mathrm{CIV}^{8,10,12,13,23,27,28}$.

CRAAs in two pastes are currently available that must be handled manually or using self-mixing applicator tips and capsules to be mechanically crushed. The constituent monomers include Bis-GMA, UDMA, HEMA, GDMA, TEGDMA and TMPTMA, as well as other conventional methacrylates. Furthermore, acidic functional monomers are found which act by demineralizing the dental substrate, eliminating the acid conditioning steps separately and favoring the material adhesion to the dental substrate, since they also form calcium compounds that bind to the hydroxyapatite crystals. Therefore, this material optimizes the operator's working time and maintains the physical and mechanical properties similar to conventional $\mathrm{CRs}^{8,24-26}$.

\subsubsection{Advantages and Indication}

CRAAs do not require prior treatment of the dental surface, since they have acidic monomers that act demineralizing and then promoting adequate infiltration of the material into the dental substrate, optimizing the adhesion process. Therefore, the cement application technique is simplified. The material manipulation is carried out and then applied to the dental substrate and the prosthetic piece in a single clinical step. Consequently, in addition to simplifying the adhesive cementing technique and optimizing clinical time, the possibility of restorative treatment contamination is reduced, promoting better adherence to procedures that require more stages in the adhesive protocol ${ }^{10,11,12,23}$.

It is also worth pointing out that, with the use of CRAAs, there is a decrease in the sensitivity of the technique, due to the single-step application. It also denotes good aesthetics, satisfactory mechanical properties, similar adherence to conventional CRs - and adherence to dentin is higher than enamel in this technique, good dimensional stability, low inflammatory response to pulp tissues and fluorides release ${ }^{13,29,30}$.

Furthermore, CRAAs are hybrid materials that combine the best properties of resin composites and self-conditioning adhesive systems, with a greater quantity of acidic monomers and a lower number of inorganic loads. Therefore, when well indicated and clinically applied, these materials present a good maintenance of their properties and less solubility in the oral environment. At the same time, in this application technique, the Smear Layer is not removed, but incorporated in the hybrid layer, thus, with the use of this technique, there is no postoperative sensitivity, confirmed by scientific evidences $2,10,12,13,30$.

However, there are still few scientific evidences that there is adequate bond strength between the CRAAs and ceramics, without the previous treatment of the restorative piece. Currently, only laboratory tests were performed using zirconia as a substrate, testing its bonding with the cement agent by the shear test ${ }^{31,32}$

\subsubsection{Adhesion Mechanism of CRAAs}

Regarding the CRAAs adherence, there are chemical and mechanical interactions between the cement agent and the dental substrate. Functional acidic monomers that promote demineralization and subsequent adhesion to the tooth are mainly methacrylate monomers with carboxylic acid and/ or phosphoric acid groups, however, after performing the demineralization necessary for the dental surface conditioning, they react to form stable salts, such as calcium salts, which act to assist in the material adhesion $6,13,29,32$.

Therefore, the acidity proposed by CRAAs is ideal enough to promote the surface energy increase in the enamel and promote the hybridization in the dentin, and chemical adhesion is always greater in dentin. Moreover, the CRAAs acidity is sufficient to dissolve the smear layer and incorporate it in the hybrid layer, excluding washing and drying steps of the dental surface. In view of the above, this material provides good chemical adhesion and micromechanical retention to restorative work similar to conventional $\mathrm{CRs}^{9,31}$.

In addition, CRAAs present a reaction of dual setting reaction, both by a photoactivation-initiated free radical polymerization pathway and by a chemical polymerization that begins at the time of the cement agent manipulation. Thus, the metallic ions of the load vitreous particles and the methacrylates acidic radicals when interacting with each other in the presence of water, in addition to neutralizing the acidity of this reaction, result in the formation of cross-connections of the cement agent monomers, creating high molecular weight polymers. In addition, there is a reaction between the acidic and dental hydroxyapatite groups, developing water release by the breakdown of this mineral, contributing to the initial hydrophilia that the cement agent needs to drain throughout the dental surface and form the first chemical bonding with 
the dental substrate, similar to the CIV adhesion mechanism $6,13,28,31,32$

It is also important to report that studies have been observed where phosphoric acid was used in the dental enamel conditioning prior to the self-adhesive cement application, resulting in better bonding resistance ${ }^{33,34}$. Following this line of thinking, other studies reported the use of polyacrylic acid in selective dental conditioning, and this in turn significantly increased the bond strength against dentin micro tractions. Therefore, it was suggested that the use of polyacrylic acid be incorporated as a cleaning step of dental substrate before the self-adhesive cement application to increase its adhesion. It is worth pointing out that, even with the increase of the cementation protocol by using acid previously and selectively on the dental surface, the cement agent will continue to be self-adhesive $\mathrm{e}^{3,6,35,36}$.

\subsubsection{Biocompatibility}

Biocompatibility can be defined as the ability of a material to be compatible with living tissues without triggering any inflammatory response in the organism.

The first study found in the literature evaluated the pulp response triggered after cementation of inlay restorations using two types of resin cements, one with previous use of adhesive system and the other with only self-adhesive resin cement. In seven days, mild to moderate inflammatory response was caused in both groups. In 60 days, the inflammatory response decreased in both groups. However, the cement resin using conventional adhesive system caused more aggressive effects to the dentin pulp complex than the self-adhesive resin cement in vitro ${ }^{5}$.

However, studies in the area suggest that CRAAs are biocompatible when there is a dentin barrier promoting protection to the pulp tissues, since the material does not require previous acid treatment and has an adequate viscosity, reducing the material penetration into the pulp tissue. However in a study evaluating direct contact between CRAAs and pulp cells, the triggering of cell apoptosis and necrosis was observed ${ }^{5,6,36}$.

\section{Conclusion}

The use of CRAAs has been increasing considerably in recent years in cementing fixed prostheses, intraradicular retainers and implant-supported prostheses, for presenting an efficient adhesion mechanism and a simple and direct use protocol. The lack of prior dental structure conditioning is its main advantage, since, in addition to reducing clinical steps of application, it also reduces possible errors in the technique that could result in failure in restorative treatment and postoperative sensitivity. However, further studies should be carried out in order to clarify the biocompatibility property of this material, its longevity of adhesive bonding and the restorative treatment longevity.

\section{References}

1. Souto Maior JR, Lima ACS, Souza FB, Silva VCH, Menezes Filho PF, Beatrice LCS. Aplicação clínica de cimento resinoso autocondicionante em restauração inlay. Odontol Clín. Cient 2010;9(1):77-81.

2. Corrêa Netto LR, Ullmann C, Silva EM, Amaral CM. Cimentos autoadesivos: uma nova possibilidade para a cimentação de restaurações indiretas. Rev Saúde UnG 2014;8(3/4):55-62.

3. Hu G, Zhang XY, Zhao JX, Zhou CJ, Wu JL. Development of novel self-adhesive resin cement with antibacterial and self-healing properties. Hua Xi Kou Qiang Yi Xue Za Zhi 2020;38(3):256-62. doi: https://doi.org/10.7518/ hxkq.2020.03.005

4. Gorodovsky S, Zidan O. Retentive strength, disintegration, and marginal quality of luting cements. J Prosthet Dent 1992;68(2):269-74. doi: https://doi.org/10.1016/00223913(92)90328-8

5. Souza Costa CA, Hebling J, Randall RC. Human pulp response to resin cements used to bond inlay restorations. Dent Mater J 2006;22(10):954-962. doi: https://doi.org/10.1016/j. dental.2005.10.007

6. Souza TR, Leão Filho JCB, Beatrice LCS. Cimentos autoadesivos: eficácias e controvérsias. Rev Dent On Line 2011;10(21): 20-25.

7. Fracasso LM, Zago RR, Nogarett LM, Lehuger G, Mota EG. Avaliação e comparação da resistência à compressão e a tração diamentral de cimentos odontológicos. Rev Unimontes Cient 2017;19(1):42-9.

8. Reis BO, Godas AGL, Suzuki TYU, Tozzi TCF, Briso ALF, Santos PH. Do Different Pretreatments of Dentine Surface Affect the Bond Strength with a Self-adhesive Resin Cement? Oral Health Prev Dent 2020;18(1):145-152. doi: https://doi. org/10.3290/j.ohpd.a43355.

9. Mazioli CG, Peçanha MM, Daroz LGD, Siqueira CQ, Fraga MAA. Resistência de união de diferentes cimentos resinosos a cerâmica à base de dissilicato de lítio. Rev Odontol UNESP 2017;46(3):174-8. doi: http://dx.doi.org/10.1590/18072577.21916

10. Oliveira NG, Lima ASLC, Silveira MT, Araújo PRS Monteiro GQM, Carvalho MV. Evaluation of postoperative sensitivity in restorations with self-adhesive resin: a randomized split-mouth design controlled study. Clin Oral Investig 2020;24(5):1829-35. doi: https://doi.org/ 10.1007/s00784019-03046-0

11. Namoratto LR, Ferreira RS, Lacerda RAV, Sampaio Filho HR, Ritto FP. Cimentação em cerâmicas: evolução dos procedimentos convencionais e adesivos. Rev Bras Odontol 2013;70(2):142-7. doi: http://dx.doi.org/10.18363/rbo. v70n2.p. 142

12. Burgess JO, Ghuman T, Cakir D. Self-adhesive resin cements. J Esthet Restor Dent 2010;22:412-9. doi: https://doi. org/10.1111/j.1708-8240.2010.00378.x

13. Ferracane JL, Stansbury JW, Burke FJ. Self-adhesive resin cements - chemistry, properties and clinical considerations. J Oral Rehabil 2011;38(4):295-314. doi: 10.1111/j.13652842.2010.02148.x

14. Brudevold F, Buonocore M, Wileman W. A report on a resin composition capable of bonding to human dentin surfaces. J Dent Res 1956;35(6):846-851. doi: https://doi.org/10.1177/0 0220345560350060401 
15. Buonocore MG. A simple method of increasing the adhesion of acrylic filling materials to enamel surfaces. J Dent Res 1955;34(6):849-853. doi: https://doi.org/10.1177/002203455 50340060801

16. Fusayama T, Nakamura M, Kurosaki N, Iwaku M. Nonpressure adhesion of a new adhesive restorative resin. J Dent Res 1979;58(4):1364-1370. doi: https://doi.org/10.1177/0022 0345790580041101

17. Sander RF, Prates LHM, Chain MC, Clavo MCM. Resistência de união ao cisalhamento de cimentos resinosos autocondicionates à dentina. Rev Clín Pesq Odontol 2009;5(3):273-9.

18. Bowen RL. Properties of a silica-reinforced polymer for dental restorations. J Am Dent Assoc 1963;66:57-64. doi: https://doi.org/10.14219/jada.archive.1963.0010

19. Da-Ré E, Gasque KCS, Moretti Neto RT. Relyx XTM U200 versus Relyx XTM ARC: uma comparação da resistência à microtração. Rev Odontol UNESP 2019;48:1-8. doi: https:// doi.org/10.1590/1807-2577.13218

20. Meharry MR, Schwartz J, Montalvo A, Mueller D, Mitchell JC. Comparison of 2 self-adhesive resin cements with or without a self-etching primer. Gen Dent 2020;68(1):22-28.

21. Machry RV, Fontana PE, Bohrer TC, Valandro F, Kaizer OB. Effect of different surface treatments of resin relined fiber posts cemented with self-adhesive resin cement on push-out and microtensile bond strength tests. Oper Dent 2020;45(4):185-95. doi: https://doi.org/10.2341/19-108-L.

22. Badini SRG, Tavares ACS, Guerra MAL, Dias NF, Vieira CD. Cimentação adesiva: revisão de literatura. Odonto 2008;16(32):105-15. doi: http://dx.doi.org/10.15603/21761000/odonto.v16n32p105-115

23. Hitz T, Stawarczyk B, Fischer J, Hammerle CH, Sailer I. Are self-adhesive resin cements a valid alternative to conventional resin cements? A laboratory study of the long-term bond strength. Dent Mater 2012;28(11):1183-90. doi: http://dx.doi. org/10.1016/j.dental.2012.09.006.

24. Blatz MB, Mante FK, Saleh N, Atlas AM, Mannan S, Ozer F. Postoperative tooth sensitivity with a new self-adhesive resin cement - a randomized clinical trial. Clin Oral Invest 2012;17:793-8. doi: https://doi.org/10.1007/s00784-0120775-4

25. Lührs AK, Guhr S, Gunay H, Geurtsen W. Shear bond strength of self-adhesive resins compared to resin cements with etch and rinse adhesives to enamel and dentin in vitro. Clin Oral Investig 2010;14(2):193-9. doi: http://dx.doi.org/10.1007/ s00784-009-0279-z.

26. Pavlinec J, Moszner N. Monomers for adhesive polymers, 8a crosslinking polymerization of selected N-substituted bis(acrylamide)s for dental filling materials. J Appl Polym Sci 2009;113(2):3137-45. doi: https://doi.org/10.1002/app.30188
27. Monticelli F, Osorio R, Mazzitelli C, Ferrari M, Toledano M. Limited decalcification / diffusion of self-adhesive cements into dentin. J Dent Res 2008;87(10):974-9. doi: https://doi. org/10.1177/154405910808701012

28. Takenaka H, Ouchi H, Sai K, Kawamoto R, Murayama R, Kurokawa K, et al. Ultrasonic measurement of the effects of light irradiation and presence of water on the polymerization of self-adhesive resin cement. Eur J Oral Sci 2015;123(5):36974. doi: http://dx.doi.org/10.1111/eos.12205.

29. Türkmen C, Durkan M, Cimilli H, Oksuz M. Tensile bond strength of indirect composites luted with three new self-adhesive resin cements to dentin. J Appl Oral Sci 2011;19(4):363-9. doi: http://dx.doi.org/10.1590/S167877572011005000011 .

30. Viana MOS, Vianna LMFF, Amaral FLB, França FMG, Turssi CP, Basting RT. Longevity of bond strength of an indirect composite resin to dentin using conventional or selfadhesive resin cementation: influence of dentin pretreatment with $\mathrm{TiF}_{4}$. Eur J Prosthodont Restor Dent 2019;27(3):103-12. doi: https://doi.org/10.1922/EJPRD_01907Viana10

31. Franco APGO, Argenta MA, Soares P, Gomes OMM, Hecke MB, Mazur RF. Investigação das propriedades mecânicas de cimentos resinosos duais convencionais e autoadesivos em macro e nanoescala. Arq Odontol 2017;53:1-7.

32. Goracci C, Cury AH, Cantoro A, Papacchini F, Tay FR, Ferrari M. Microtensile bond strength and interfacial properties of self-etching and self-adhesive resin cements used to lute composite onlays under different seating forces. J Adhes Dent 2006;8(5):327-35.

33. Hikita K, Van Meerbeek B, De Munck J, Ikeda T, Van Landuyt $\mathrm{K}$, Maida T,et al. Bonding effectiveness of adhesive luting agents to enamel and dentin. Dent Mater 2007;23(1):71-80. doi: https://doi.org/10.1016/j.dental.2005.12.002

34. de Munk J, Vargas M, Landuyt KV, Hikita K, Lambrechts $\mathrm{P}$, Van Meerbeek B. Bonding of an auto-adhesive luting material to enamel and dentin. Dent Mater 2004;20(10):96371. doi: https://doi.org/10.1016/j.dental.2004.03.002

35. Pavan S, dos Santos PH, Berger S, Bedran-Russo AK. The effect of dentin pretreatment on the microtensile bond strength of self-adhesive resin cements. J Prosthet Dent 2010;104(4):258-64. doi: https://doi.org/10.1016/S00223913(10)60134-5

36. Chrisostomo DA, Steazzi-Sahyon HB, Briso AFF, Santos PH. Efficacy of Polyacrylic Acid as a Conditioning Agent on the Bond Strength of Self-adhesive Resin Cements to Dental Enamel. Oral Health Prev Dent 2020;18(1):747-56. doi: https://doi.org/ 10.3290/j.ohpd.a45078

37. Garcia LFR, Pontes ECV, Basso FG, Hebling J, Costa CAS, Soares DG. Transdentinal cytotoxicity of resin-based luting cements to pulp cells. Clin Oral Invest 2015;1(1):1-8. doi: http://dx.doi.org/10.1007/s00784-015-1630-1. 